\title{
PENERAPAN ETIKA LINGKUNGAN DALAM PENGELOLAAN WILAYAH KEPESISIRAN TUBAN
}

\author{
Dini Atikawati ${ }^{1}$, Totok Gunawan ${ }^{2}$ dan Sunarto ${ }^{2}$ \\ ${ }^{1}$ Program Doktor Ilmu Lingkungan, Sekolah Pascasarjana, UGM, \\ Jl. Teknika Utara, Pogung Kidul, Yogyakarta 55281 \\ ${ }^{2}$ Fakultas Geografi, UGM, Sekip Utara, Jl. Kaliurang, Bulaksumur, Yogyakarta 55281
}

\begin{abstract}
Abstrak: Wilayah kepesisiran Tuban memiliki sumberdaya pesisir yang melimpah. Masyarakat pesisir Tuban memanfaatkannya untuk perikanan, wisata, dan permukiman. Berbagai macam pemanfaatan tersebut menimbulkan terjadinya kerusakan lingkungan, sehingga dipandang perlu untuk menerapkan etika lingkungan dalam pengelolaan wilayah kepesisiran Tuban. Penelitian ini bertujuan untuk mengidentifikasi profil wilayah kepesisiran Tuban, mengkaji dinamika pantai di Tuban, mengkaji perilaku masyarakat terhadap wilayah kepesisiran Tuban, dan merumuskan penerapan etika lingkungan dalam pengelolaan wilayah kepesisiran Tuban. Data diperoleh melalui observasi, pengukuran, wawancara, dan potret lapangan. Analisis data yang digunakan yaitu deskriptif dan skoring. Hasil penelitian menunjukkan bahwa wilayah kepesisiran Tuban di daerah penelitian memiliki dua jenis pantai, yaitu pantai berbatu dan berpasir. Keempat daerah penelitian memiliki hidrologi yang tawar. Keanekaragaman flora dan fauna pesisir paling tinggi di Desa Panyuran, sedangkan paling rendah di Desa Karangagung. Dinamika pantai di daerah penelitian yaitu erosi, akresi, dan keadaan seimbang. Erosi pantai terjadi di Desa Karangagung dan Kelurahan Kutorejo. Akresi terjadi di Desa Panyuran. Keadaan seimbang terjadi di Kelurahan Sukolilo. Nilai perilaku masyarakat terhadap wilayah kepesisiran masih tergolong rendah. Etika lingkungan dalam pengelolaan wilayah kepesisiran Tuban dilakukan dengan penerapan paradigma biosentrisme dan ekosentrisme.
\end{abstract}

Kata kunci : etika lingkungan, pengelolaan, wilayah kepesisiran

\section{A. PENDAhuluan}

Wilayah kepesisiran merupakan wilayah yang kaya akan sumberdaya alam dan memiliki potensi untuk mendukung program pembangunan berkelanjutan, sehingga wilayah ini menjadi tempat strategis untuk berbagai kegiatan manusia, seperti perikanan, permukiman, pariwisata, perindustrian, perdagangan, pelabuhan, dan pertambangan (Supriharyono, 2000; Gunawan, dkk., 2005; Marfai, 2013). Berbagai bentuk kegiatan yang ada di pesisir menyebabkan semakin beragamnya permasalahan yang menimpa pesisir (Marfai, 2014).

Wilayah kepesisiran juga merupakan wilayah yang sangat dinamis dengan berbagai macam proses fisik, seperti kenaikan muka air laut, land subsidence, dan erosi-sedimentasi (Marfai, dkk., 2011). Semua proses tersebut memengaruhi dinamika wilayah kepesisiran. Adanya potensi besar yang dimiliki dan proses fisik yang dinamis menyebabkan wilayah ini semakin 
mudah terkena dampak negatif, seperti kerusakan dan pencemaran.

Kerusakan dan pencemaran wilayah kepesisiran semakin mengkhawatirkan. Sebagai contoh, sampah plastik telah mengotori wilayah pesisir di Pantura Jawa yang mengakibatkan banyak ikan mati karena memakan plastik. Sampah dan limbah yang dihasilkan oleh manusia bertambah sangat cepat, tidak sebanding dengan kemampuan lingkungan untuk menyerapnya (Marpaung, 1997).

Kabupaten Tuban merupakan salah satu kabupaten yang memiliki desadesa pesisir dengan potensi sumberdaya pesisir yang melimpah. Masyarakat pesisir Tuban memanfaatkan wilayah kepesisiran untuk perikanan, wisata, dan permukiman. Permukiman yang dibangun tidak memerhatikan perlunya sempadan pantai sehingga sangat dekat dengan pantai, kalaupun ada sempadan pantai berupa tanah kosong yang dijadikan tempat membuang sampah. Sampah juga masih banyak ditemukan menumpuk di pinggir pantai.

Sumber dari berbagai masalah lingkungan sebenarnya disebabkan oleh kesalahan paradigma antroposentrisme yang memandang manusia sebagai pusat segala sesuatu dan alam dianggap hanya memiliki nilai ekonomis untuk kepentingan manusia. Manusia dan alam merupakan entitas terpisah. Paradigma seperti ini yang melahirkan perilaku merusak (Hamzah, 2013; Keraf, 2014).

Di sisi lain, kenyataan yang dihadapi, pengelolaan lingkungan yang bertanggung jawab sampai saat ini masih memprihatinkan (Hamzah, 2013). Pengelolaan lingkungan hendaknya menjamin pemanfaatannya secara bijaksana dan menjamin kesinambungan persediaannya dengan tetap memelihara dan meningkatkan nilai dan keanekaragamannya (Birowo, 2016).

Paradigma terhadap pengelolaan lingkungan juga hendaknya mulai diperbaiki dengan memandangnya sebagai tindakan yang menunjukkan rasa hormat dan toleransi manusia terhadap komponen abiotik dan biotik yang ada di suatu lingkungan, sehingga pemahaman tentang etika lingkungan perlu dikedepankan dalam setiap program pembangunan (Marfai, 2005). Berdasarkan uraian di atas, maka dipandang perlu untuk menerapkan etika lingkungan dalam pengelolaan wilayah kepesisiran Tuban.

Tujuan penelitian ini adalah untuk mengidentifikasi profil wilayah kepesisiran Tuban, mengkaji dinamika pantai di Tuban, mengkaji perilaku masyarakat terhadap wilayah kepesisiran Tuban, dan merumuskan penerapan etika lingkungan dalam pengelolaan wilayah kepesisiran Tuban. 


\section{B. METODE}

Penelitian ini merupakan penelitian deskriptif yang menggunakan pendekatan survei. Penelitian ini dilakukan di empat desa/kelurahan pesisir yang terdapat di Kabupaten Tuban, yaitu Desa Karangagung dan Panyuran di Kecamatan Palang serta Kelurahan Sukolilo dan Kutorejo di Kecamatan Tuban, yang dilaksanakan pada bulan Januari sampai dengan Maret 2017.

Pengumpulan data diperoleh dengan cara observasi, pengukuran, wawancara, dan potret lapangan. Identifikasi profil wilayah kepesisiran Tuban dilakukan pengukuran, observasi, dan potret lapangan yang meliputi pengukuran kemiringan tepi pantai dan observasi jenis pantai, penggunaan lahan, hidrologi, serta flora dan fauna yang ada di wilayah kepesisiran.

Kajian dinamika pantai dilakukan dengan pengukuran sudut kemiringan tepi pantai dan median ukuran sedimen ke-50 kemudian dihitung menggunakan indeks $G_{0}$ untuk penentuan erosi dan akresi pantai. Penentuan erosi dan akresi pantai menurut Sunamura dan Hirokawa (1974, dalam CERC, 1984) sebagai berikut.

$\mathrm{G}_{0}=\left(\mathrm{H}_{0} / \mathrm{L}_{0}\right)(\operatorname{tg} \delta)^{0,27}\left(\mathrm{~d}_{50} / \mathrm{L}_{0}\right)^{-0,67}$

Keterangan:

$\mathrm{G}_{0}=$ parameter untuk menentukan erosi atau akresi pantai dengan kriteria
$\mathrm{G}_{0}<0,0556=$ erosi pantai, $\mathrm{G}_{0}>$

$0,111=$ akresi pantai,

$\mathrm{H}_{0}=$ ting gi gelombang $(\mathrm{m})$,

$\mathrm{T}=$ periode gelombang $(\mathrm{s})$

$\mathrm{L}_{0}=$ panjang gelombang $(\mathrm{m})$,

$\mathrm{g}=\operatorname{gravitasi}\left(9,81 \mathrm{~m} / \mathrm{s}^{2}\right)$,

$\delta=$ sudut kemiringan tepi pantai $\left(^{\circ}\right)$

$\mathrm{d}_{50}=$ median ukuran sedimen ke-50

(mm).

Kajian perilaku masyarakat terhadap wilayah kepesisiran Tuban dilakukan dengan wawancara, observasi, dan potret lapangan yang menggunakan instrumen non tes berupa panduan wawancara. Panduan wawancara menggunakan skala pengukuran berupa skala sikap. Skala sikap digunakan untuk mengukur sikap, pendapat, dan persepsi seseorang tentang fenomena social (Widoyoko, 2016).

Rumusan etika lingkungan pengelolaan wilayah kepesisiran Tuban didasarkan pada hasil identifikasi profil wilayah kepesisiran, kajian dinamika pantai, dan kajian perilaku masyarakat terhadap wilayah kepesisiran Tuban.

Pengambilan sampel untuk identifikasi profil wilayah kepesisiran Tuban dilakukan dengan memerhatikan penggunaan lahan yang ada di pesisir (permukiman, wisata pantai, dan TPI) dan jenis pantai (berbatu dan berpasir). Pengambilan sampel responden untuk kajian perilaku masyarakat masingmasing desa/kelurahan sejumlah 30 orang. 
Pengambilan sampel responden untuk masing-masing desa/kelurahan sejumlah 35 orang yang terdiri dari 30 orang masyarakat pesisir dan lima orang perangkat desa/kelurahan. Terdapat empat desa/kelurahan sampel, sehingga jumlah responden sebanyak 140 orang. Pengambilan sampel tiap desa/kelurahan sejumlah 30 orang didasarkan pada teori sampling bahwa sampel terkecil dan dapat mewakili distribusi normal adalah 30 (Tika, 2005).

Analisis data yang digunakan dalam penelitian ini yaitu analisis deskriptif kualitatif, kuantitatif, dan skoring. Analisis deskriptif kualitatif dan kuantitatif diperlukan untuk menganalisis hasil pengukuran di lapangan, observasi, wawancara, dan potret lapangan.

Analisis skoring digunakan untuk menganalisis skala sikap hasil wawancara responden. Analisis skoring yang digunakan mengacu pada skala Likert. Peneliti menggunakan skala Likert model empat pilihan (skala empat). Skala disusun dalam bentuk pernyataan dan diikuti oleh pilihan sikap yang menunjukkan tingkatan. Pemilihan skala empat dimaksudkan agar tidak ada peluang bagi responden untuk bersikap netral sehingga memaksa responden untuk menentukan sikap terhadap fenomena sosial yang dinyatakan dalam instrument (Widoyoko, 2016; Azwar, 2009).
Tabel 1. Skoring Skala Likert

\begin{tabular}{|l|c|c|}
\hline \multicolumn{1}{|c|}{ Kategori Sikap } & Skor & Klasifikasi Skor \\
\hline SL (selalu) & 4 & $>113,75-140$ \\
SR (sering) & 3 & $>87,50-113,75$ \\
P (pernah) & 2 & $>61,25-87,50$ \\
TP (tidak pernah) & 1 & $35-61,25$ \\
\hline
\end{tabular}

\section{HASIL DAN PEMBAHASAN}

\section{Profil Wilayah Kepesisiran Tuban}

Kabupaten Tuban merupakan kota pesisir yang memiliki panjang $65 \mathrm{~km}$ membentang dari timur Kecamatan Palang sampai barat Kecamatan Bancar. Kota pesisir ini memiliki sumberdaya yang melimpah sehingga sangat potensial untuk perkembangan bidang perikanan dan wisata.

Wilayah kepesisiran Tuban merupakan dataran rendah dengan ketinggian $0-15 \mathrm{mdpl}$.

Wilayah kepesisiran Tuban yang menjadi daerah penelitian memiliki dua jenis tanah, yaitu mediteran merah kuning yang terdapat di Kecamatan Palang dan aluvial yang terdapat di Kecamatan Palang dan Tuban.

Sebagian besar wilayah kepesisiran Tuban memiliki iklim yang kering dengan kondisi bervariasi dari agak kering sampai sangat kering. Sumber air tawar berasal dari kawasan resapan air, mata air, dan sungai.

Berdasarkan hasil penelitian, profil wilayah kepesisiran Tuban dapat dilihat pada Gambar 1. dan Tabel 2. 


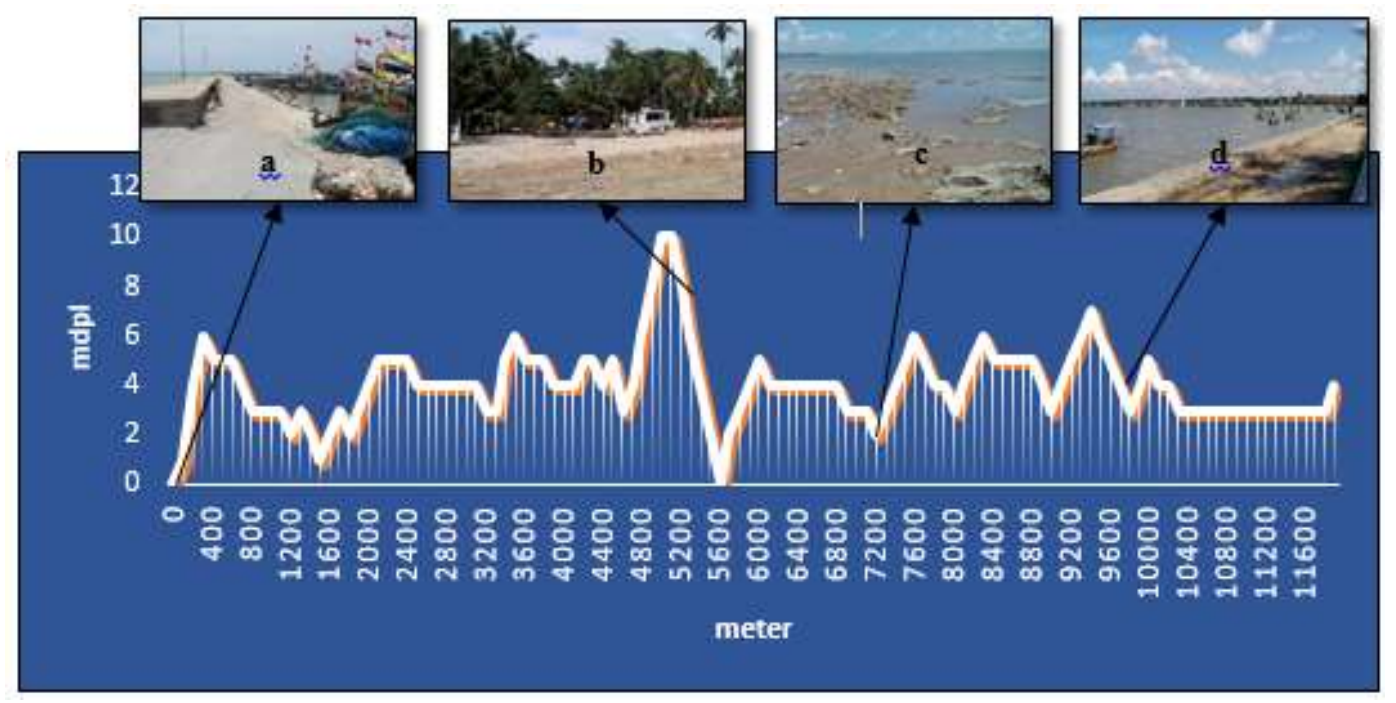

Gambar 1. Tracking Horizontal Wilayah Kepesisiran Tuban

Tabel 2. Profil Wilayah Kepesisiran Tuban

\begin{tabular}{lcccc}
\hline \multicolumn{1}{c}{ No Sampel } & $\mathrm{a}$ & $\mathrm{b}$ & $\mathrm{c}$ & $\mathrm{d}$ \\
\hline Lokasi & PPI Karangagung & Pantai Kelapa & Pantai Sukolilo & Pantai Boom \\
Desa/Kelurahan & Karangagung & Panyuran & Sukolilo & Kutorejo \\
Kecamatan & Palang & Palang & Tuban & Tuban \\
mdpl & 0 & 8 & 2 & 4 \\
Jenis Pantai & Berbatu & Berpasir & Berpasir & Berbatu \\
Pengg.Lahan & TPI & Wisata & Permukiman & Wisata \\
Lereng & $0^{\circ}$ & $5^{\circ}$ & $5^{\circ}$ & $5^{\circ}$ \\
Hidrologi & Tawar & Tawar & Tawar & Tawar \\
Flora dan & Ikan, Keong laut & Kelapa, Cemara, Waru, & Bakau, Rumput, & Cemara, \\
Fauna & kecil, Kepiting & Lamtoro, Semut, Laba- & Lalat, Ikan, & Rumput, \\
& kampat & laba, Kupu-kupu, Lalat, & Kepiting bakau, & Keong lau \\
& & Kepiting pasir, Keong laut & Semut, Laba-laba & kecil, Kepiting \\
& & kecil, Ikan, Siput laut & & kampat, Ikan \\
\hline
\end{tabular}

Sumber: Hasil Pengamatan, 2017

Berdasarkan Gambar 1. dan Tabel

2. diketahui bahwa wilayah kepesisiran

di daerah penelitian memiliki dua jenis pantai, yaitu pantai berbatu dan berpasir. Pantai berbatu terdapat di Desa Karangagung dengan penggunaan lahan untuk PPI (Pelabuhan Pendaratan Ikan) dan Kelurahan Kutorejo dengan penggunaan lahan untuk wisata pantai yang terkenal dengan nama Pantai Boom.

Dahulu Pantai Boom merupakan pelabuhan transit perdagangan antarpulau dan antarnegara yang kemudian berubah menjadi wisata pantai bersejarah. Sedangkan pantai berpasir terdapat di Desa Panyuran dengan penggunaan lahan untuk wisata pantai yang terkenal dengan nama Pantai Kelapa dan Kelurahan Sukolilo dengan penggunaan lahan untuk permukiman.

PPI Karangagung memiliki ketinggian 0 mdpl dengan lereng $0^{\circ}$. 
Pantai Kelapa memiliki ketinggian 8 mdpl dengan lereng $5^{\circ}$. Pantai Sukolilo memiliki ketinggian 2 mdpl dengan lereng $5^{\circ}$. Pantai Boom memiliki ketinggian 4 mdpl dengan lereng $5^{\circ}$.

Keempat daerah penelitian memiliki hidrologi yang tawar. Keanekaragaman jenis flora dan fauna yang tinggi terdapat di Pantai Kelapa. Sedangkan keanekaragaman jenis flora dan fauna yang rendah terdapat di PPI Karangagung.

\section{Dinamika Pantai di Tuban}

Wilayah kepesisiran merupakan wilayah yang sangat dinamis dengan berbagai proses yang terjadi di dalamnya. Proses tersebut meliputi erosi, akresi, dan keadaan seimbang antara erosi dan akresi. Erosi dan akresi merupakan hal yang normal terjadi di alam, akan tetapi pengelolaan wilayah kepesisiran yang salah menyebabkan semakin tingginya kejadian erosi ataupun akresi yang dapat menimbulkan dampak negatif terhadap wilayah kepesisiran. Hasil pengukuran dinamika pantai menggunakan Indeks $\mathrm{G}_{0}$ disajikan pada Tabel 3.

Tabel 3. Dinamika Pantai di Daerah Penelitian

\begin{tabular}{cllccc}
\hline $\begin{array}{c}\text { No } \\
\text { Sampel }\end{array}$ & \multicolumn{1}{c}{$\begin{array}{c}\text { Desa/ } \\
\text { Kelurahan }\end{array}$} & \multicolumn{1}{c}{ Lokasi } & $\begin{array}{c}\text { Jenis } \\
\text { Pantai }\end{array}$ & $\begin{array}{c}\text { Nilai } \\
\text { Indeks G }\end{array}$ & Fenomena \\
\hline E.1 & Karangagung & PPI Karangagung & Berbatu & 0,0233 & erosi \\
E.2 & Panyuran & Wisata Pantai Kelapa & Berpasir & 0,1429 & akresi \\
E.3 & Sukolilo & Pantai Sukolilo & Berpasir & 0,0912 & seimbang \\
E.4 & Kutorejo & Wisata Pantai Boom & Berbatu & 0,0366 & erosi \\
\hline
\end{tabular}

Sumber: Hasil Pengukuran, 2017

Berdasarkan Tabel 3. diketahui bahwa erosi pantai terjadi di PPI Karangagung dan Pantai Boom. Kedua lokasi ini memiliki kesamaan, yaitu jenis pantai berbatu. Kondisi di lapangan, PPI Karangagung sangat panas karena tidak terdapat pepohonan sama sekali. Sempadan pantai berupa lahan kosong yang luas ditumbuhi rumput liar yang dipenuhi sampah berserakan. Lahan kosong tersebut digunakan sebagai tempat membuang sampah warga sekitar. Lahan kosong tersebut berdekatan

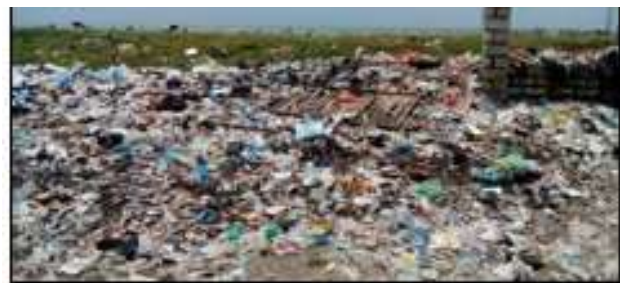

Gambar 2. Sempadan Pantai di PPI Karangagung yang dipenuhi sampah

Pantai Boom dahulu digunakan sebagai dermaga transit perdagangan, sehingga dibangun panjang ke arah laut. Ombak yang besar di laut menghantam bangunan dermaga yang sekarang dijadikan tempat wisata secara terus menerus sehingga rawan terjadi erosi. dengan permukiman yang sangat padat. 


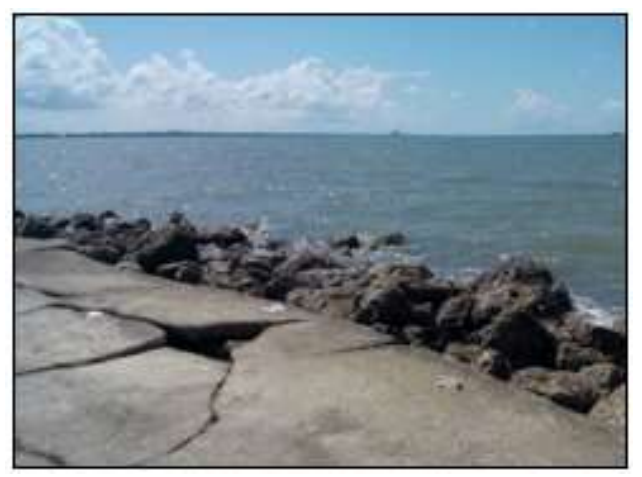

Gambar 3. Bangunan Dermaga Pantai Boom yang retak oleh ombak

Akresi terjadi di Pantai Kelapa dan keadaan seimbang antara erosi dan akresi terjadi di Pantai Sukolilo. Pantai Kelapa dan Sukolilo memiliki jenis pantai berpasir. Kondisi di lapangan, Pantai Kelapa dipenuhi pohon kelapa yang menjadi sempadan pantai. Sedangkan di Pantai Sukolilo, ditanami bakau dan cemara laut yang dijadikan sempadan pantai.

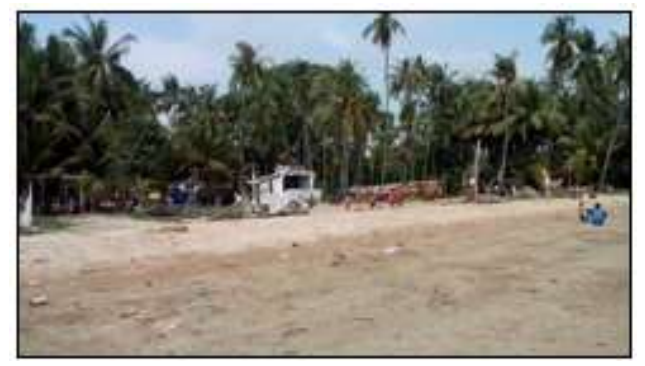

Gambar 4. Pantai Kelapa Panyuran

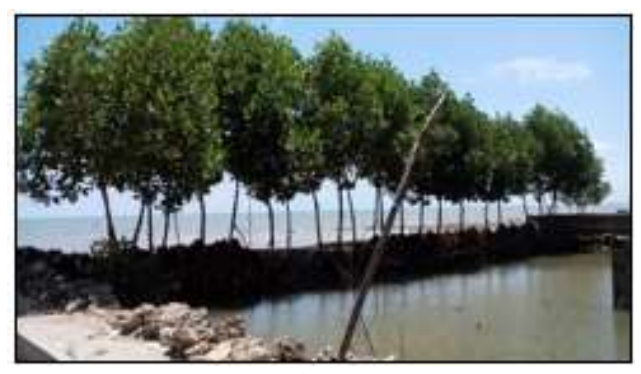

Gambar 5. Pantai Sukolilo yang ditanami bakau

\section{Perilaku Masyarakat terhadap Wilayah Kepesisiran Tuban}

Masyarakat melakukan berbagai macam aktivitas di wilayah kepesisiran untuk memenuhi kebutuhan hidupnya terutama kebutuhan ekonomi dan rekreasi, sehingga wilayah kepesisiran dimanfaatkan sebagai tempat pelelangan ikan dan wisata. Pemanfaatan tersebut bisa membawa dampak positif atau negatif tergantung perilaku masyarakat dalam mengelolanya.

Perilaku yang baik akan menjamin keberlanjutan nilai wilayah kepesisiran, sebaliknya perilaku yang tidak baik akan merusak bahkan menghilangkan nilainilai wilayah kepesisiran. Perilaku masyarakat terhadap wilayah kepesisiran Tuban disajikan pada Tabel 4.

Berdasarkan Tabel 4. diketahui bahwa rata-rata nilai perilaku masyarakat terhadap wilayah kepesisiran Tuban berada pada klasifikasi "pernah" dan "tidak pernah". Hal ini menunjukkan kepedulian masyarakat terhadap lingkungan pesisir masih tergolong rendah.

Perilaku masyarakat dalam memanfaatkan wilayah kepesisiran untuk kebutuhan rekreasi paling tinggi ada di Kelurahan Kutorejo. Tempat rekreasinya yaitu Pantai Boom. 
Tabel 4. Perilaku Masyarakat terhadap Wilayah Kepesisiran Tuban

\begin{tabular}{|c|c|c|c|c|c|}
\hline \multirow[t]{2}{*}{ No } & \multirow[t]{2}{*}{ Pernyataan } & \multicolumn{4}{|c|}{ Nilai Perilaku Masyarakat (\%) } \\
\hline & & Karangagung & Panyuran & Sukolilo & Kutorejo \\
\hline \multirow[t]{2}{*}{1} & Saya pergi ke pantai untuk & 53,57 & 78,57 & 55,71 & 82,86 \\
\hline & rekreasi & (P) & $(\mathrm{SR})$ & (P) & $(\mathrm{SL})$ \\
\hline \multirow[t]{2}{*}{2} & Saya ikut serta dalam penghijauan & 29,29 & 32,86 & 45,00 & 35,00 \\
\hline & wilayah pesisir & $(\mathrm{TP})$ & $(\mathrm{TP})$ & (P) & $(\mathrm{TP})$ \\
\hline \multirow[t]{2}{*}{3} & Saya ikut serta memelihara & 66,43 & 87,86 & 85,71 & 89,29 \\
\hline & $\begin{array}{l}\text { kebersihan pantai (tidak } \\
\text { membuang sampah di pantai) }\end{array}$ & $(\mathrm{SR})$ & $(\mathrm{SL})$ & $(\mathrm{SL})$ & (SL) \\
\hline \multirow[t]{2}{*}{4} & Saya menegur jika ada orang yang & 34,29 & 39,29 & 37,14 & 30,00 \\
\hline & membuang sampah/hajat di pantai & $(\mathrm{TP})$ & $(\mathrm{TP})$ & $(\mathrm{TP})$ & $(\mathrm{TP})$ \\
\hline \multirow[t]{2}{*}{5} & Saya menegur jika ada orang yang & 26,43 & 30,00 & 27,86 & 31,43 \\
\hline & menebang tanaman pantai & $(\mathrm{TP})$ & $(\mathrm{TP})$ & $(\mathrm{TP})$ & $(\mathrm{TP})$ \\
\hline \multirow[t]{2}{*}{6} & Saya menegur jika ada orang & 46,43 & 30,71 & 27,14 & 29,29 \\
\hline & $\begin{array}{l}\text { yang menangkap ikan dengan } \\
\text { pukat harimau/racun/bom }\end{array}$ & (P) & $(\mathrm{TP})$ & (TP) & (TP) \\
\hline & Rata-rata & $\begin{array}{l}42,74 \\
\text { (TP) }\end{array}$ & $\begin{array}{c}49,88 \\
\text { (P) }\end{array}$ & $\begin{array}{c}46,43 \\
(\mathrm{P})\end{array}$ & $\begin{array}{c}49,65 \\
(\mathrm{P})\end{array}$ \\
\hline
\end{tabular}

Sumber: Pengolahan Hasil Wawancara, 2017

Keterangan: SL=Selalu; SR=Sering; P=Pernah; TP=Tidak Pernah

Kelurahan Kutorejo merupakan kota dengan penduduk yang sangat padat dan merupakan pusat kegiatan di Kota Tuban. Berbagai macam infrastruktur dan gedung pemda ada disana, sehingga masyarakatnya perlu untuk rekreasi dari suasana yang sangat bising.

Perilaku baik seperti ikut serta dalam penghijauan wilayah pesisir paling tinggi di Kelurahan Sukolilo yaitu sebesar $45 \%$ dan termasuk dalam klasifikasi "pernah", artinya masyarakat Sukolilo pernah ikut serta dalam penghijauan di wilayah pesisir. Kondisi di lapangan ditunjukkan dengan terdapatnya pohon cemara laut dan bakau sebagai sempadan pantai meskipun jumlahnya masih sedikit.
Perilaku baik lainnya seperti memelihara kebersihan pantai, nilai paling tinggi terdapat di Kelurahan Kutorejo yaitu sebesar 89,29\% yang termasuk klasifikasi "selalu", artinya masyarakat Kutorejo selalu menjaga kebersihan pantai.

Perilaku menegur apabila melihat orang lain melakukan hal yang tidak baik masih rendah. Hal ini dikarenakan ada beberapa alasan, yaitu dirinya juga masih melakukan hal yang sama, tidak peduli, tidak berani (tidak mau cari masalah), dan memang tidak ada orang yang perlu ditegur. Masyarakat Desa Karangagung dan Panyuran masih banyak yang membuang hajat di pantai, sehingga alasan tidak menegur dikarenakan mereka juga melakukan hal yang sama. 
4. Penerapan etika lingkungan dalam pengelolaan wilayah kepesisiran Tuban

Pengelolaan wilayah kepesisiran sangat penting untuk menjamin keberlanjutan sumberdaya yang ada di pesisir sehingga dapat dirasakan juga oleh generasi mendatang. Pengelolaan yang salah akan menimbulkan kerusakan. Penerapan etika lingkungan dalam pengelolaan wilayah kepesisiran disajikan pada Tabel 5.

Tabel 5. Penerapan Etika Lingkungan dalam Pengelolaan Wilayah Kepesisiran

\begin{tabular}{|c|c|c|}
\hline No & $\begin{array}{l}\text { Paradigma Etika } \\
\text { Lingkungan }\end{array}$ & Pengelolaan Wilayah Kepesisiran \\
\hline 1 & Biosentrisme & $\begin{array}{l}\text { - Penghijauan sempadan pantai } \\
\text { - Menangkap ikan dengan menggunakan alat yang ramah lingkungan } \\
\text { - Tidak membuang sampah di wilayah kepesisiran }\end{array}$ \\
\hline 2 & Ekosentrisme & $\begin{array}{l}\text { - Penghijauan sempadan pantai } \\
\text { - Tidak membuang sampah di wilayah kepesisiran } \\
\text { - Pelarangan kegiatan reklamasi dan penambangan di wilayah } \\
\text { kepesisiran } \\
\text { - Pelaksanaan kearifan lokal masyarakat pesisir, seperti petik laut dan } \\
\text { bersih desa } \\
\text { - Adanya area konservasi di wilayah kepesisiran, seperti konservasi } \\
\text { mangrove, terumbu karang, ikan hias }\end{array}$ \\
\hline
\end{tabular}

Etika lingkungan dalam pengelolaan wilayah kepesisiran Tuban dilakukan dengan penerapan paradigma biosentrisme dan ekosentrisme. Biosentrisme memandang bahwa setiap kehidupan dan makhluk hidup memunyai nilai yang berharga pada dirinya sendiri, sehingga sumberdaya pesisir seperti ikan, terumbu karang, dan vegetasi pantai tidak dianggap sebagai sesuatu yang bernilai ekonomis saja tetapi juga perlu untuk dijaga kelestariannya.

Ekosentrisme merupakan kelanjutan dari biosentrisme. Ekosentrisme memandang bahwa semua komponen dalam suatu lingkungan baik biotik maupun abiotik memunyai nilai yang berharga pada dirinya sendiri dan membentuk satu kesatuan hubungan saling tergantung sebagai tatanan ekosistem yang menyeluruh. Adanya gangguan pada salah satu komponen, akan menyebabkan terganggunya keseimbangan ekosistem, sehingga semua komponen yang ada di wilayah kepesisiran dianggap sangat penting untuk dijaga keberlanjutannya.

\section{SIMPULAN}

Wilayah kepesisiran Tuban yang menjadi daerah penelitian memiliki dua jenis pantai, yaitu pantai berbatu dan berpasir. Pantai berbatu terdapat di Desa Karangagung dan Kelurahan Kutorejo. Sedangkan pantai berpasir terdapat di Desa Panyuran dan Kelurahan Sukolilo. Keempat daerah penelitian memiliki 
hidrologi yang tawar. Keanekaragaman jenis flora dan fauna yang tinggi terdapat di Desa Panyuran. Sedangkan keanekaragaman jenis flora dan fauna yang rendah terdapat di Desa Karangagung.

Dinamika pantai di daerah penelitian ada tiga, yaitu erosi, akresi, dan seimbang antara erosi dan akresi. Erosi pantai terjadi di Desa Karangagung dan Kelurahan Kutorejo. Akresi terjadi di Desa Panyuran. Keadaan seimbang antara erosi dan akresi terjadi di Kelurahan Sukolilo.

$$
\text { Nilai perilaku masyarakat }
$$
terhadap wilayah kepesisiran Tuban berada pada klasifikasi "pernah" dan "tidak pernah". Hal ini menunjukkan kepedulian masyarakat terhadap lingkungan pesisir masih tergolong rendah.

Etika lingkungan dalam pengelolaan wilayah kepesisiran Tuban dilakukan dengan penerapan paradigma biosentrisme dan ekosentrisme.

\section{UCAPAN TERIMA KASIH}

Dengan ini saya mengucapkan terima kasih kepada penyelenggara Program Beasiswa Unggulan, Biro Perencanaan dan Kerjasama Luar Negeri, Sekretariat Jenderal, Kementrian Pendidikan dan Kebudayaan TA 2015/2016 yang telah memberikan beasiswa biaya pendidikan kepada saya untuk melanjutkan studi jenjang S3.

\section{DAFTAR PUSTAKA}

Azwar, S., 2009. Metode Penelitian. Pustaka Pelajar, Yogyakarta.

Birowo, $\quad$ M.A.M.W., 2016. Mengembangkan Kompetensi Etis di Lingkungan Kita. Grasindo, Jakarta.

CERC, 1984. Shore Protection Manual Volume I. US Army Corps of Engineers, Washington.

Gunawan, T., Santosa, L.W., Muta'ali, L., dan Santosa, S.H.M.B., 2005. Pedoman Survei Cepat Terintegrasi Wilayah Kepesisiran. Badan Penerbit dan Percetakan Fakultas Geografi, Yogyakarta.

Hamzah, S., 2013. Pendidikan Lingkungan: Sekelumit Wawasan Pengantar. Refika Aditama, Bandung.

Keraf, A.S., 2014. Filsafat Lingkungan Hidup: Alam sebagai Sebuah Sistem Kehidupan Bersama Fritjof Capra. Kanisius, Yogyakarta.

Marfai, M.A., 2005. Moralitas Lingkungan: Refleksi Kritis Atas Krisis Lingkungan Berkelanjutan. Wahana Hijau (WeHa), Yogyakarta.

Marfai, M.A., dkk., 2011. Model Kerentanan Wilayah Pesisir Berdasarkan Perubahan Garis Pantai dan Banjir Pasang (Studi Kasus: Wilayah Pesisir Pekalongan). MPPDAS Fakultas Geografi UGM, Yogyakarta.

Marfai, M.A., 2013. Pengantar Etika Lingkungan dan Kearifan Lokal. Gadjah Mada University Press, Yogyakarta.

Marfai, M.A., 2014. Banjir Pesisir: Kajian Dinamika Pesisir Semarang. Gadjah Mada University Press, Yogyakarta.

Marpaung, L., 1997. Tindak Pidana Lingkungan Hidup dan Masalah Prevensinya. Sinar Grafika, Jakarta.

Supriharyono, 2000. Pelestarian dan Pengelolaan Sumber Daya Alam di Wilayah Pesisir Tropis. Gramedia Pustaka Utama, Jakarta.

Tika, M.P., 2005. Metode Penelitian Geografi. Bumi Aksara, Jakarta.

Widoyoko, E.P., 2016. Teknik Penyusunan Instrumen Penelitian. Pustaka Pelajar, Yogyakarta. 